\title{
Broiler feed formulated with phosphorus, calcium, and energy deficiencies supplemented with exogenous enzymes
}

\section{Rações para frangos formuladas com deficiências de fósforo, cálcio e energia suplementada com enzimas exógenas}

\author{
Rodrigo de Freitas Jacob ${ }^{1 *}$; Luiz Fernando Teixeira Albino²; Arele Arlindo \\ Calderano2; Romário Duarte Bernardes ${ }^{3}$; Horácio Santiago Rostagno2; \\ Maurílio de Lucas Xavier Júnior ${ }^{1}$; Renan Hernandes Lino ${ }^{4}$; Warley Júnior Alves ${ }^{1}$; \\ Samuel Oliveira Borges ${ }^{4}$; Thiago Ferreira Diana ${ }^{1}$
}

\section{Highlights}

Nutrient deficiency impairs broiler performance.

Adding enzymes to reduced-nutrient diets maintains performance and reduces costs.

Enzymes improve energy use, which can reflect on improved performance.

The greater digestibility of amino acids may explain the increase in performance.

Phytases, carboidrases and proteases are able to improve the amino acids values.

\section{Abstract}

Three experiments were carried out to verify the effects of the enzyme phytase, alone or combined with an enzyme complex, in diets deficient in available phosphorus (AP), calcium (Ca), and metabolizable energy (ME) on broiler performance, $\mathrm{ME}$, and dietary amino acid digestibility. A total of 1,538 male Cobb 500 broilers were allocated to the three experiments, each of which consisted of five treatments: positive control (PC; basal ration); negative control 1 (NC1; PC minus $0.15 \%$ of $\mathrm{AP}, 0.16 \%$ of $\mathrm{Ca}$, and $68 \mathrm{kcal} \mathrm{kg}-1 \mathrm{ME}$ ); negative control 2 (NC2; PC minus $0.15 \%$ of $A P, 0.16 \%$ of $\mathrm{Ca}$, and $101 \mathrm{kcal} \mathrm{kg}^{-1}$ of ME); NC1 plus phytase; and NC2 plus phytase plus enzymatic complex. Body weight gain (WG) and feed intake were measured from 1-21

1 Students of Animal Science Doctoral Course, Department of Animal Science, Unversidade Federal de Viçosa, UFV, Viçosa, MG, Brazil. E-mail: rodrigofj2@gmail.com; maurilio_junior1@hotmail.com; warleyjunioralves@hotmail.com; thiagofnet@hotmail.com

2 Profs. Drs., Postgraduate Program in Animal Science, Department of Animal Science, UFV, Viçosa, MG, Brazil. E-mail: lalbino@ufv.br; calderano@ufv.br; rostagno@ufv.br

${ }^{3}$ Student of Animal Science Master's Course of the Postgraduate Program in Animal Science, Department of Animal Science, UFV, Viçosa, MG, Brazil. E-mail: romario.bernardes@ufv.br

${ }^{4}$ Students of Animal Science Undergraduate Course, Department of Animal Science, UFV, Viçosa, MG, Brazil. E-mail: renan.lino@ufv.br; samuelborges1001@gmail.com

* Author for correspondence

Received: Mar. 02, 2021 - Approved: June 01, 2021 
days and from 1-42 days, and the corrected feed conversion rate (FCR) for mortality was calculated. In the second and third experiments, the apparent ME corrected for nitrogen balance (AMEn) and standardized digestibility of amino acids, respectively, were determined, for the diets supplemented with phytase and the enzymatic complex. In the first experiment, enzyme supplementation increased $(p<0.05)$ WG at 21 days and 42 days relative to the negative controls. Phytase inclusion improved $(p<0.05)$ FCR at the initial phase compared to the NC1 diet. In the second experiment, enzyme supplementation did not affect $(p>0.05)$ AMEn. In the third experiment, both enzyme treatments improved $(p<0.05)$ the digestibility of amino acids in the supplemented diets compared to the deficient diets. Supplementation with phytase and carbohydrases preserves the performance of broilers fed diets deficient in AP, $\mathrm{Ca}$, and ME and improves amino acid digestibility.

Key words: Broilers. Performance. Phytase. Metabolism. Enzymatic complex.

\section{Resumo}

Três experimentos foram conduzidos para determinar o efeito da enzima fitase, sozinha ou associada a um complexo enzimático, em dietas de milho-farelo de soja deficientes em fósforo disponível (Pd), cálcio (Ca) e energia metabolizável (EM) no desempenho de frangos de corte, valores de EM e digestibilidade de aminoácidos da dieta. Para ambos os experimentos, 1.538 frangos Cobb 500 machos foram alocados em 5 tratamentos: controle positivo (CP, ração basal), controle negativo 1 (CN1, CP menos 0,15\% de Pd, 0,16\% Ca e $68 \mathrm{kcal} \mathrm{kg}^{-1} \mathrm{EM}$ ), negativo controle 2 (CN2, CP menos 0,15\% de Pd, 0,16\% de Ca e $101 \mathrm{kcal} \mathrm{kg}^{-1}$ de $\mathrm{ME}$ em relação à dieta $\mathrm{CP}), \mathrm{CN} 1$ mais fitase $(\mathrm{CN} 1+\mathrm{F})$ e CN2 mais fitase mais complexo multienzimático (CN2 + F + E). O ganho de peso corporal e o consumo de ração foram medidos de 1 a 21 dias e de 1 a 42 dias, e a taxa de conversão alimentar (CA) corrigida para mortalidade foi calculada. No segundo e terceiro experimentos, foram analisados os valores de energia metabolizável aparente corrigida para o balanço de nitrogênio (EMAn) e digestibilidade estandardizada de aminoácidos, respectivamente, em adição à fitase e ao complexo enzimático. No primeiro experimento, a suplementação enzimática aumentou $(P<$ 0,05 ) o ganho de peso (GP) aos 21 dias e 42 dias em relação aos controles negativos. A inclusão de fitase melhorou $(P<0,05)$ a taxa de conversão alimentar na fase inicial, em comparação com a dieta CN1. No segundo experimento, a suplementação enzimática não afetou $(P>0,05)$ os valores de EMAn. No terceiro experimento, ambos os tratamentos enzimáticos melhoraram $(P<0,05)$ a digestibilidade dos aminoácidos nas dietas experimentais, em comparação com as dietas deficientes. A suplementação de fitase e carboidrases preserva o desempenho de frangos alimentados com dietas deficientes em Pd, Ca e EM e melhora a digestibilidade dos aminoácidos.

Palavras-chave: Frangos de corte. Desempenho. Fitase. Metabolismo. Complexo enzimático.

\section{Introduction}

Corn and soybean meal, the most important ingredients in broiler feed, contain varying concentrations of antinutritional factors that can substantially reduce the digestibility of dietary nutrients, and, therefore, animal performance. Exogenous enzymes are added to feed in an attempt to counter the adverse effects of these factors and improve the nutritional value of the diet. 
Phytases are enzymes that catalyze the hydrolysis reaction of the phytate phosphate ester bonds, and thereby not only promote an increase in the bioavailability of phosphorus (P) but also positively affect energy and amino acid values in broiler diets (Dersjant-Li, Awati, Schulze, \& Partridge, 2015; Bournazel et al., 2018). Information on the interaction between phytases and carbohydrases is inconclusive. However, it is known that although the target substrates of these enzymes are different in corn and soybean meal, carbohydrases can improve the accessibility of exogenous and endogenous enzymes to the cellular contents of plant tissue. Thus, the more complete breakdown of plant cell walls stimulated by carbohydrases can increase the additive or sub-additive benefits of broiler diets based on corn and soybean meal (Schramm et al., 2017).

Exogenous proteases are enzymes with growing potential for use in diets for nonruminant animals. They mitigate the negative impacts of factors such as lectins, trypsin inhibitors, and allergenic proteins, and can improve energy use and increase amino acid values in broiler diets (Cowieson \& Roos, 2016). The influence of enzyme combinations on performance, amino acid digestibility, and energy of broiler diets has been evaluated by several authors. In most cases, enzymes were added to diets containing deficient levels of calcium (Ca), available phosphorus (AP), and energy, particularly in evaluations of phytase, xylanase, and protease (Walk \& Poernama, 2018)

This study tests the hypothesis that supplementation with phytase alone, or in combination with carbohydrases and protease, can improve the use of nutrients and energy in the diet and preserve the performance of broilers fed nutrient- and energy-deficient diets based on corn and soybean meal. Thus, the objective was to evaluate the effects of supplementation with phytase, alone or combined with an enzyme complex, of diets deficient in AP, $\mathrm{Ca}$, and metabolizable energy (ME) on broiler performance, $\mathrm{ME}$, and amino acid digestibility.

\section{Materials and Methods}

This study was conducted at the Teaching, Research, and Extension Unit in Production and Nutrition of Poultry of the Animal Science Department, Agricultural Sciences Center, Federal University of Viçosa (UFV), Viçosa, the State of Minas Gerais, Brazil (2045'57.19"S, 42 $51^{\circ} 35.42^{\prime \prime} \mathrm{W}$ and $682 \mathrm{~m}$ altitude). All experimental procedures adopted were previously approved by the Ethics Committee on the Use of Farm Animals (process no. 0107/2018) in accordance with the ethical principles of animal experimentation established by the National Council for Animal Experimentation Control (CONCEA) and current legislation.

Two basal diets based on corn and soybean meal were formulated for experiments at the initial and growth/finisher phases, following the nutritional recommendations of Rostagno et al. (2017) (Table 1). The study included three experiments with the same five treatments: positive control ( $\mathrm{PC}$; basal ration); negative control 1 ( $\mathrm{NC} 1$; a reduction by $0.15 \%$ of $\mathrm{AP}, 0.16 \%$ of $\mathrm{Ca}$, and $68 \mathrm{kcal} \mathrm{kg}^{-1}$ of $\mathrm{ME}$ relative to the $\mathrm{PC}$ diet); negative control 2 (NC2; a reduction by $0.15 \%$ of $A P, 0.16 \%$ of $\mathrm{Ca}$, and $101 \mathrm{kcal} \mathrm{kg}^{-1}$ of ME relative to the $\mathrm{PC}$ diet); NC1 with the addition of phytase (NC1 + Phy); and NC2 with the addition of phytase and an enzyme complex (NC2 + Phy + E). 
Table 1

Composition and calculated nutritional values of Positive Control (PC) and Negative Controls (NC) diets

\begin{tabular}{|c|c|c|c|c|c|c|}
\hline \multirow{2}{*}{ Ingredients (\%) } & \multicolumn{3}{|c|}{1 to 21 days } & \multicolumn{3}{|c|}{22 to 42 days } \\
\hline & $\mathrm{PC}^{1}$ & $\mathrm{NC}^{2}{ }^{2}$ & $\mathrm{PC}^{1}$ & $\mathrm{NC}^{2}{ }^{2}$ & $\mathrm{PC}^{1}$ & $\mathrm{NC}^{2}{ }^{2}$ \\
\hline Corn & 50.531 & 55.338 & 57.398 & 59.240 & 64.048 & 66.964 \\
\hline Soybean meal & 41.422 & 39.363 & 38.307 & 32.686 & 30.627 & 28.823 \\
\hline Soybean oil & 3.846 & 1.867 & 1.045 & 4.500 & 2.526 & 1.366 \\
\hline Dicalcium phosphate & 1.786 & 0.981 & 0.985 & 1.491 & 0.685 & 0.694 \\
\hline Limestone & 0.924 & 1.039 & 0.860 & 0.715 & 0.831 & 0.840 \\
\hline Salt & 0.515 & 0.427 & 0.427 & 0.472 & 0.384 & 0.384 \\
\hline DL-Methionine (99\%) & 0.318 & 0.304 & 0.304 & 0.253 & 0.239 & 0.245 \\
\hline Biolys $\mathrm{HCl}(54,6 \%)$ & 0.135 & 0.171 & 0.171 & 0.160 & 0.196 & 0.218 \\
\hline L-Threonine (98\%) & 0.048 & 0.035 & 0.028 & 0.033 & 0.019 & 0.021 \\
\hline Vitamin ${ }^{4}$ & 0.130 & 0.130 & 0.130 & 0.100 & 0.100 & 0.100 \\
\hline Mineral $^{5}$ & 0.130 & 0.130 & 0.130 & 0.100 & 0.100 & 0.100 \\
\hline Choline chloride (60\%) & 0.100 & 0.100 & 0.100 & 0.100 & 0.100 & 0.100 \\
\hline Salinomycin ${ }^{6}(12 \%)$ & 0.055 & 0.055 & 0.055 & 0.055 & 0.055 & 0.055 \\
\hline $\mathrm{BHT}^{7}$ & 0.010 & 0.010 & 0.010 & - & - & - \\
\hline Starch & 0.010 & 0.010 & 0.010 & 0.010 & 0.010 & 0.010 \\
\hline Total & 0.040 & 0.040 & 0.040 & 0.050 & 0.050 & 0.050 \\
\hline Corn & 100 & 100 & 100 & 100 & 100 & 100 \\
\hline \multicolumn{7}{|c|}{ Nutritional composition (\%) } \\
\hline Metabolizable energy kcal/kg & 3000 & 2942 & 2899 & 3150 & 3092 & 3049 \\
\hline Crude protein \% & 23.228 & 22.703 & 22.383 & 19.934 & 19.409 & 18.854 \\
\hline Calcium \% & 0.930 & 0.777 & 0.777 & 0.758 & 0.598 & 0.598 \\
\hline Av. phosphorus \% & 0.440 & 0.290 & 0.290 & 0.374 & 0.224 & 0.224 \\
\hline Sodium \% & 0.218 & 0.183 & 0.183 & 0.200 & 0.165 & 0.165 \\
\hline Dig. lysine \% & 1.256 & 1.241 & 1.218 & 1.070 & 1.055 & 1.032 \\
\hline Dig. methionine + cysteine \% & 0.929 & 0.906 & 0.900 & 0.792 & 0.769 & 0.763 \\
\hline Dig. threonine \% & 0.829 & 0.799 & 0.782 & 0.706 & 0.676 & 0.659 \\
\hline
\end{tabular}

${ }^{1} \mathrm{PC}=$ positive control (diet meeting the nutritional requirements of broilers).

${ }^{2} \mathrm{NC} 1$ = negative control 1 (PC minus $68 \mathrm{kcal} / \mathrm{kg} \mathrm{EM} ; 0,15 \% \mathrm{AP}$ and 0,16\% Ca).

The enzyme complex (SQzyme CEM, Suntaq International Limited, Shenzhen, China), originating from Trichoderma reesei (601-17), contained predominantly carbohydrases, and was composed of $\alpha$-galactosidase, $\beta$-mannanase, pectinase, xylanase, acid cellulase, $\alpha$-amylase, $\beta$-glucanase, and protease (Table 2). It was applied at a dose of $100 \mathrm{~g} / \mathrm{t}$ of diet to provide a guaranteed minimum of $100,1,500,1,500$, $15,000,1,200,150,2,400$, and 2,500 units per $\mathrm{kg}$ of diet of $\alpha$-galactosidase, $\beta$-mannanase, 
pectinase, xylanase, acid cellulase, $\alpha$-amylase, $\beta$-glucanase, and protease, respectively. Phytase was derived from Escherichia coli
(EC 3.1.3.26), modified by Pichia pastoris, and supplied at a rate of $500 \mathrm{FTU} \mathrm{kg}^{-1}$ of diet.

\section{Table 2}

Definition and enzymatic properties of enzymes added to diets

\begin{tabular}{|c|c|c|c|c|c|}
\hline \multirow[b]{2}{*}{ Enzymes } & \multicolumn{5}{|c|}{ Definition $^{1}$} \\
\hline & Molecule released & Substrate & $\begin{array}{l}\text { Reaction } \\
\text { time }\end{array}$ & $\mathrm{pH}$ & Temperature \\
\hline Phytase & $1 \mu \mathrm{mol}$ of inorganic $\mathrm{P}$ & Sodium Phytate & $1 \mathrm{~min}$ & 5.5 & $37^{\circ} \mathrm{C}$ \\
\hline$\alpha$-Galactosidase & $1 \mu \mathrm{mol}$ de $\mathrm{p}$-nitrophenol & $\begin{array}{l}\text { p-Nitrophenyl- } \alpha-D- \\
\text { Galactopyranoside }\end{array}$ & $1 \mathrm{~min}$ & 6.0 & $37^{\circ} \mathrm{C}$ \\
\hline$\beta$-Mananase & $1 \mu \mathrm{mol}$ of mannose & Galactomanan & $1 \mathrm{~min}$ & 5.0 & $70^{\circ} \mathrm{C}$ \\
\hline Pectinase & $\begin{array}{c}1 \mu \mathrm{mol} \text { of D-galacturonic } \\
\text { acid }\end{array}$ & Polygalacturonic Acid & $1 \mathrm{~min}$ & 5.0 & $37^{\circ} \mathrm{C}$ \\
\hline Xilanase & $1 \mu \mathrm{mol}$ de xylose & Xylan & $1 \mathrm{~min}$ & 5.0 & $50^{\circ} \mathrm{C}$ \\
\hline Celulase & $1 \mu \mathrm{mol}$ de glucose & Filtered paper & $1 \mathrm{~min}$ & 4.8 & $50^{\circ} \mathrm{C}$ \\
\hline$\alpha$-Amylase & $1 \mu \mathrm{mol}$ de glicose & Starch & $5 \min$ & 6.9 & $40^{\circ} \mathrm{C}$ \\
\hline$\beta$-Glucanase & $1 \mu \mathrm{mol}$ de glucose & Carboxymethylcellulose & $1 \mathrm{~min}$ & 4.8 & $50^{\circ} \mathrm{C}$ \\
\hline Protease & $\begin{array}{c}1 \mu \mathrm{mol} \text { of Suc-Ala-Ala-Pro- } \\
\text { Phe-N-succinyl Ala-Ala- } \\
\text { Pro-Phe-p-nitroanilide }\end{array}$ & $p$-Nitroaniline & $1 \min$ & 9.0 & $37^{\circ} \mathrm{C}$ \\
\hline
\end{tabular}

${ }^{1}$ Quantity of enzyme required to release $1 \mu \mathrm{mol}$ of a given molecule from the substrate at a given time, $\mathrm{pH}$ and temperature.

In the performance experiment, 1,000 one-day-old Cobb 500 male chicks were weighed $(43.78 \pm 0.025 \mathrm{~g}$ each) and distributed in the treatments to ensure that the treatments had similar average body weights. The birds were randomly distributed in the five treatments, each with 10 replicates of 20 chicks each. Each stall containing the 20 chicks was considered an experimental unit and consisted of a box with a concrete floor, with dimensions of $1.25 \times 1.80 \mathrm{~m}$ and a total area of $2.25 \mathrm{~m}^{2}$. The animals were handled in $3 \mathrm{~m}$ high masonry sheds with asbestos cement tiles, $50 \mathrm{~cm}$ low walls, and a screen with a 0.5-inch mesh adapted for animal experimentation. The performance parameters evaluated were feed intake $(\mathrm{Fl}, \mathrm{g})$, weight gain (WG, g), and feed conversion rate (FCR, $\mathrm{g} \mathrm{g}^{-1}$ ). Body weight and $\mathrm{Fl}$ were recorded at 21 days and 42 days. Mortality was recorded daily for subsequent Fl correction according to Sakomura and Rostagno (2016). Feed and water were provided ad libitum throughout the experimental period. The broiler bed consisted of new sawdust.

In the metabolism experiment, 240 male Cobb 500 broilers were housed in cages containing trays lined with plastic for the collection of total excreta. Each cage was equipped with a bird feeder and waterer for 
ad libitum access to feed and water. The birds were distributed in a completely randomized design, with five treatments, eight replicates, and six birds per experimental unit. The broilers were initially fed a commercial diet based on corn and soybean meal for 13 days and subsequently introduced to the experimental diets.

The total excreta were collected from day 19 to day 23 to determine the apparent ME corrected for nitrogen balance (AMEn). After an adaptation period of four days (days 14-18), excreta were collected twice a day (at 8 am and $6 \mathrm{pm}$ ) for four consecutive days (days 19-23). At the end of the excreta collection period, the samples were thawed at room temperature and homogenized, and the subsamples were placed in plastic containers and stored in a freezer at $-18^{\circ} \mathrm{C}$ until analysis.

Excreta and feed samples were dried at $55^{\circ} \mathrm{C}$ in a forced ventilation oven for $72 \mathrm{~h}$. The samples were ground on a $1 \mathrm{~mm}$ screen. The dry matter (DM) content was determined by drying the samples overnight in an oven at 105 ${ }^{\circ} \mathrm{C}$ (Detmann et al., 2012). The Kjeldahl method was used to determine the nitrogen content in diets and excreta according to standard protocols (Detmann et al., 2012). The excreted nitrogen (NE) was calculated by multiplying the total amount excreted in the DM by the percentage of nitrogen in the excreta, also in the DM. The same method was applied to the calculation of the nitrogen consumed (NC). Nitrogen retention (NR) was determined as the amount of NC minus NE. The gross energy content was measured with a C5001 adiabatic calorimetric pump (IKA-Werke $\mathrm{GmbH}$ \& Co. KG, Staufen, Germany). The AMEn values were calculated based on the analysis of diets and excreta according to Sakomura and Rostagno (2016).
In the digestibility experiment, 288 male Cobb 500 broilers were housed in cages, distributed in a completely randomized design, with five treatments, eight replicates, and six birds per experimental unit. To obtain the coefficients of standardized ileal digestibility (CSIDs) of amino acids, a protein-free diet was used to determine the endogenous excretion of amino acids (Table 3). The birds received the experimental diet from 16 to 20 days of age. Celite ${ }^{\circledR}$ (Celite Corp., Lompoc, CA, USA), a source of acid insoluble ash (AIA), was added to all diets at $10 \mathrm{~g} \mathrm{~kg}^{-1}$ as an indigestible marker, and AIA concentrations were determined by the method of Van Keulen and Young (1977).

After a five-day adaptation period, all birds were killed by cervical dislocation and the abdominal cavity was opened immediately to expose the digestive tract. The $15 \mathrm{~cm}$ ileum terminal segment was sectioned $4 \mathrm{~cm}$ from the ileocecal junction to access the ileal digesta. The ileal samples were frozen and stored at $-20^{\circ} \mathrm{C}$ until processing. They were then lyophilized for $72 \mathrm{~h}$ at $-40^{\circ} \mathrm{C}$ in a lyophilizer ( $\mathrm{LH}$ 0401, Terroni, São Carlos, Brazil).

Dry matter analysis (Detmann et al., 2012) of the diets and ileal digesta was performed for digestibility calculations. Laboratory analysis to determine the amino acid content of diets and excreta was carried out by CBO - Analises Laboratoriais (Campinas, São Paulo, Brazil) using HPLC (high performance liquid chromatography). The digestibility of amino acids was calculated based on the analysis of diets and ileal digesta according to Sakomura and Rostagno (2016). 
Table 3

Protein-free diet composition

\begin{tabular}{|c|c|}
\hline Ingredients & PFD (\%) \\
\hline Starch & 81.240 \\
\hline Sugar & 5.000 \\
\hline Soybean oil & 5.000 \\
\hline Dicalcium phosphate & 2.100 \\
\hline Limestone & 0.700 \\
\hline Salt & 0.450 \\
\hline Cob $^{1}$ & 4.000 \\
\hline Vitamin ${ }^{2}$ & 0.150 \\
\hline Mineral $^{3}$ & 0.150 \\
\hline Choline cloride (60\%) & 0.200 \\
\hline $\mathrm{BHT}^{4}$ & 0.010 \\
\hline Acid insoluble ash (Celite ${ }^{T M}$ ) & 1.000 \\
\hline Total & 100.000 \\
\hline Crude protein (\%) & 0.174 \\
\hline
\end{tabular}

${ }^{1}$ Considering cob with $4.4 \% \mathrm{CP}$.

${ }^{2}$ Vit. 9375 IU; Vit. D3 2375 IU; Vit E 35 IU; Vit B1 2.50 mg; Vit B2 6.25 mg; Vit B6 3.5 mg; Vit B12 0.015 mg; Nicotinic acid $37.5 \mathrm{mg}$; Pantothenic Acid 12.5mg; Vit. K3 1.88mg; Folic acid 0.875mg; Biotin 0.088 mg.

${ }^{3}$ Selenium - 0.375 mg; Manganese - 88 mg; Iron 62.5 mg; Zinc 81.3 mg; Copper 12.5 mg; lodine 1.25 mg.

${ }^{4}$ Antioxidant Butyl Hydroxy Toluene.

Broiler performance, ME, and digestibility of amino acids were analyzed with ANOVA using the software $\mathrm{R}$ ( $\mathrm{R}$ Core Team, 2019). Boxes or cages were considered experimental units. A probability of $p<0.05$ was considered statistically significant. The Tukey test was used to identify differences between means at the significance level $p<$ 0.05 .

The statistical model used was

$$
Y i j=\mu+\tau i+\varepsilon i j,
$$

where $Y_{i j}$ was the observation of the ith treatment in the jth experimental unit (response variable), $\mu$ was the general mean, ti was the treatment effect, and $\varepsilon$ ij was the experimental error.

\section{Results and Discussion}

In the performance experiment (121 days), only the birds in the NC1 treatment had a lower $\mathrm{FI}$ compared to those in the PC treatment ( $p<0.05$; Table 4$)$. In addition, the FI of birds in the NC2 + Phy + E treatment was higher $(p<0.05)$ than that of the birds in NC2. The decrease in ME was generally offset by the increase in $\mathrm{Fl}$. However, the reduction in phosphorus $(\mathrm{P})$ showed the opposite trend by being associated with reduced FI (Walk \& Rama Rao, 2020). However, these effects depend on the degree of AP reduction in the diet. For example, Ziarat, Kermanshahi, Mogaddam and Heravi (2020) did not observe a reduction in FI 
at the initial phase in broilers fed P-deficient diets, and related the lack of response to the
$P$ deficiency, which was only $0.11 \%$ of $A P$ relative to $\mathrm{PC}$, not being high enough.

\section{Table 4}

\section{Effect of exogenous enzymes on broiler performance}

\begin{tabular}{|c|c|c|c|c|c|c|c|}
\hline \multirow[b]{2}{*}{ Variable } & \multicolumn{5}{|c|}{ Treatment } & \multirow[b]{2}{*}{ SEM } & \multirow[b]{2}{*}{ P-value } \\
\hline & $\mathrm{PC}^{1}$ & $\mathrm{NC}^{2}{ }^{2}$ & $\mathrm{NC}^{3}{ }^{3}$ & NC1 + Phy & NC2 + Phy + E & & \\
\hline \multicolumn{8}{|c|}{ 1-21 days } \\
\hline WG (g) & $986 a$ & $856 b$ & $882 b$ & $990 a$ & $975 a$ & 0.00139130 & 0.001 \\
\hline $\mathrm{FI}(\mathrm{g})$ & $1263 a b$ & $1171 \mathrm{c}$ & $1191 \mathrm{bc}$ & 1237abc & $1309 a$ & 0.00152249 & 0.001 \\
\hline FCR & $1.285 a b$ & $1.369 c$ & $1.353 b c$ & $1.250 a$ & $1.343 \mathrm{bc}$ & 0.001535364 & 0.001 \\
\hline \multicolumn{8}{|c|}{ 1-42 days } \\
\hline WG (g) & $2995 a$ & $2916 b$ & $2915 b$ & $2997 a$ & $2998 a$ & 0.00446046 & 0.010 \\
\hline $\mathrm{FI}(\mathrm{g})$ & $5066 a$ & $4812 a$ & $4995 a$ & $5077 a$ & $5061 a$ & 0.00160478 & 0.047 \\
\hline FCR & 1.68 & 1.65 & 1.71 & 1.69 & 1.69 & 0.00145384 & 0.437 \\
\hline
\end{tabular}

a-c Means in the same row with different letters differ significantly $(P<0.05)$ by Tukey's test.

Abbreviations: $E$, enzymatic complex; WG, weight gain (g); FI, feed intake (g); FC, feed conversion (g/g).

${ }^{1} \mathrm{PC}=$ positive control (diet meeting the nutritional requirements of broilers).

${ }^{2} \mathrm{NC} 1=$ negative control 1 (PC minus $68 \mathrm{kcal} / \mathrm{kg} \mathrm{EM} ; 0,15 \% \mathrm{AP}$ and $\left.0,16 \% \mathrm{Ca}\right)$.

${ }^{3} \mathrm{NC} 2$ = negative control 2 (PC minus $101 \mathrm{kcal} / \mathrm{kg} \mathrm{EM;} \mathrm{0,15 \%} \mathrm{AP} \mathrm{and} \mathrm{0,16 \%} \mathrm{Ca).}$

The WG of birds in treatments NC1 and NC2 was lower in the period from 1 to 21 days, compared to birds in treatments PC, NC1 + Phy, and NC2 + Phy + E $(p<0.05)$. The negative effect of AP reduction is not only observed in the birds' food intake; AP deficiency can lead to anorexia and, therefore, to less weight gain (Montanhini, Ceccantini, \& Fernandes, 2012; Rahimi, Modirsanei, \& Mansoori, 2020). In addition to slowing growth, animals become less efficient in using nutrients from the diet. This lower efficiency may be attributed to the negative effect of phytate on the endogenous flow of amino acids (Cowieson \& Ravindran, 2007).

However, as hypothesized, when the birds received diets supplemented with phytase or phytase + enzyme complex, their WG did not change relative to that of the birds in the control treatment, and they recovered a part of the lost performance. The results of this study are consistent with those of Dessimoni et al. (2019) who also observed an improvement in performance after adding phytase to diets deficient in P. Likewise, Ribeiro et al. (2016) showed a positive effect on $\mathrm{FI}$ and WG of phytase addition to P-deficient diets. Walk, Pirgozliev, Juntunen, Paloheimo and Ledoux (2018) found that the addition of phytase, phytase + xylanase, or the combination of phytase + xylanase + protease to diets deficient in $\mathrm{P}$ and $\mathrm{Ca}$ restored $\mathrm{FI}$ and $\mathrm{WG}$ and improved the feeding efficiency of birds. This result can be explained by the positive effect of enzymes on nutrient release from the diet 
and performance. According to Walk, Santos and Bedford (2014), improvements in FCR can be attributed to the degradation of phytate by phytase and the use of inositol. Other studies have also shown that the inclusion of phytase in broiler diets can improve the ileal digestibility of $\mathrm{P}$, amino acids, and proteins and ME (Rutherfurd, Chung, Thomas, Zou, \& Moughan, 2012; Pieniazek et al., 2017).

In addition, the beneficial effects of inclusion of carbohydrases with phytase on bird performance can be justified by the increase in the nutritional value of the diet, which occurs from the moment $\mathrm{P}$ deficiency is overcome by phytase and the intake of nutrients is restored, thereby compensating for the reduction in ME (Francesch \& Geraert, 2009). Corn and soybean meal are highly digestible ingredients, but they can include significant amounts of non-starch polysaccharides (PNAs; 8-29\%). In maize, the main PNAs are arabinoxylans and $\beta$-galactomannan, while in soy bran, $\alpha$-galactosides and $\beta$-galactomannan predominate (Choct, 1997; Malathi \& Devegowda, 2001; Jamroz, Jakobsen, Knudsen, Wiliczkiewicz, \& Orda, 2002; Amerah, 2015; Jaworski, Lærke, Bach Knudsen, \& Stein, 2015). In diets based on corn and soybean meal, carbohydrases are associated with the rupture of the cell wall matrix, facilitating the release of encapsulated nutrients and their access by both endogenous and exogenous enzymes, as in the case of phytase access to the molecule phytate (Olukosi, Cowieson, \& Adeola, 2007; Diana et al., 2020). This evidence corroborates the hypothesis that the use of a combination of carbohydrases and phytase in broiler diets can potentiate their effects, which can be additive or sub-additive in diets based on corn and soybean meal (Cowieson \& Bedford, 2009; Schramm et al., 2017).
The action of exogenous proteases on dietary proteins may improve performance and increase protein digestibility and amino acid absorption in broilers (Fru-Nji, Kluenter, Fischer, \& Pontoppidan, 2011; Mahmood et al., 2017). However, performance effects are expected to be evident only in situations where protein digestibility is naturally impaired or when dietary amino acids are reduced (Amerah, Romero, Awati, \& Ravindran, 2016). In this study, the activity of protease, supplemented at only $2,500 \mathrm{U} / \mathrm{kg}$, does not seem to have been sufficient to promote additive performance responses in the birds. In addition, the ad libitum supply of feed may have made it difficult to detect the effects of the enzyme. Similarly, Yuan, Wang, Zhang and Wang (2017) did not observe significant improvements in the performance of broilers fed diets based on corn and soybean meal supplemented with carbohydrases (xylanase, beta-glucanase, and cellulase) and protease (at 50,000 U/kg).

Between days 1 and 42, the reduction in the levels of $A P, C a$, and ME in the NC diets resulted in significantly worse WG in birds compared to that in birds fed the PC diet $(p<0.05)$. However, FI or FCR responses to the reduction in nutrients were not significant, although they were numerically lower than the responses to the PC diet. Supplementation of the deficient diet with phytase or the enzyme complex caused a body weight gain in birds similar to that with the standard diet. These results agree with the findings of previous studies that phytases or enzyme complexes added to corn and soybean meal-based diets deficient in $\mathrm{AP}, \mathrm{Ca}$, and $\mathrm{ME}$ improved the growth rate of broilers (Lu et al., 2013; Dessimoni et al., 2019; Rahimi et al., 2020). 
There were no treatment effects on AMEn ( $p>0.05$; table 5). The absence of any effect of phytase on AMEn is compatible with the findings of previous studies (Rutherfurd et al., 2012; Akter, Graham, \& lji, 2017). However, this result is at odds with the previous finding that phytase has positive effects on energy retention in birds (Pieniazek et al., 2017; Gallardo, Dadalt, \& Trindade, 2018). These conflicting results may be due to several factors, such as the concentration of phytic acid in the diet, types of ingredient used, age of birds, and digestibility coefficients of fat, starch, and amino acids (Cowieson, Aureli,
Guggenbuhl, \& Fru-Nji, 2015). In addition, it is noteworthy that phytase can improve the net energy of production in broilers without causing significant effects on AMEn (Olukosi \& Adeola, 2008). According to Akter et al. (2017), this is because an amount of energy remains locked in protein and fat in the body and this energy is reflected in the value of net energy rather than in the value of AME. This further indicates that the measurement of net energy may be more appropriate for assessing the effect of phytase. The Phy + E combination also did not have an effect on AMEn.

\section{Table 5}

Apparent metabolizable energy corrected for nitrogen balance in diets for broilers supplemented with exogenous enzymes

\begin{tabular}{|c|c|c|c|c|c|c|c|}
\hline \multirow[b]{2}{*}{ Variable } & \multicolumn{5}{|c|}{ Treatment } & \multirow[b]{2}{*}{ SEM } & \multirow[b]{2}{*}{ P-value } \\
\hline & $\mathrm{PC}^{1}$ & $\mathrm{NC}{ }^{2}$ & $\mathrm{NC}^{3}{ }^{3}$ & NC1 + Phy & NC2 + Phy + E & & \\
\hline \multicolumn{8}{|l|}{ EMAn } \\
\hline Calculated & 3000 & 2942 & 2899 & 3000 & 3000 & & \\
\hline Determinated & 3062 & 3023 & 3012 & 3049 & 3061 & 2.02657 & 0.665 \\
\hline $\begin{array}{l}\text {-cMeans in the sa } \\
\text { Abbreviations: } \mathrm{E} \\
\mathrm{PC}=\text { positive } \mathrm{col} \\
\mathrm{NC} 1 \text { = negative } \\
\mathrm{NC} 2 \text { = negative }\end{array}$ & $\begin{array}{l}\text { w with } \\
\text { latic co } \\
\text { liet me } \\
1 \text { (PC } \\
2 \text { (PC }\end{array}$ & $\begin{array}{l}\text { ent lette } \\
x ; \text { AMEn } \\
\text { the nutr } \\
\text { s } 68 \mathrm{kca} \\
\text { s } 101 \mathrm{kc}\end{array}$ & $\begin{array}{l}\text { fer signif } \\
\text { arent me } \\
\text { r require } \\
\text { M; } 0,15 \% \\
\text { EM; } 0,15\end{array}$ & $\begin{array}{l}\text { ntly }(P<0.05) \\
\text { olizable energ } \\
\text { nts of broilers) } \\
\text { and } 0,16 \% \text { and } 0,16 \%\end{array}$ & $\begin{array}{l}\text { Tukey's test. } \\
\text { (kcal/kg). } \\
\text { a). }\end{array}$ & & \\
\hline
\end{tabular}

However, previous studies have shown improvements in nutrient and energy retention with supplementation of poultry diets with phytase + carbohydrase or phytase + carbohydrase + protease (Romero, Parsons, Utterback, Plumstead, \& Ravindran, 2013; Murugesan, Romero, \& Persla, 2014; Gallardo, Dadalt, Kiarie, \& Trindade, 2017; Gallardo, Dadalt, \& Trindade, 2019). The main reasons attributed to these observations are better access by digestive enzymes of the plant cell wall matrices, reduction of antinutritional factors, and endogenous losses (Meng \& Slominsky, 2005; Olukosi \& Adeola, 2008; Gallardo et al., 2017). According to Amerah, Plumstead, Barnard and Kumar (2014), the response of birds to enzymes in terms of energy improvement can vary depending on the energy content of the basal diet, the level of substrate and inherent digestibility, 
intestinal health, and the effect of enzymes on the microbiota profile. Thus, the high digestibility of the ingredients used in the diets of this study may have contributed to the lack of responses in energy use.

To obtain the CSIDs of amino acids for the different diets, a protein-free diet was used to determine the loss of endogenous amino acids ( $\mathrm{g} / \mathrm{kg} \mathrm{DM})$. The CSIDs of arginine, isoleucine, leucine, lysine, phenylalanine, valine, aspartic acid, glutamic acid, glycine, and serine were similar between treatments PC, NC1, and NC2 (Table 6). However, supplementation of the NC1 treatment with phytase improved the digestibility of arginine, isoleucine, leucine, phenylalanine, aspartic acid, glutamic acid, and serine compared to the NC1 diet without supplementation. The addition of the combined enzymes (Phy + E) improved the digestibility of arginine, isoleucine, lysine, phenylalanine, threonine aspartic acid, and serine relative to the $\mathrm{NC2}$ $\operatorname{diet}(p<0.05)$.

The CSIDs of histidine and alanine in the PC diet were higher than those in the NC1 and NC2 diets. The use of phytase alone or in combination (Phy + E) significantly increased the digestibility coefficient of histidine compared to the respective negative controls; however, only phytase improved the digestibility of alanine relative to the negative control $(p<0.05)$.

The digestibility of the amino acids methionine, threonine, cystine, proline, and tyrosine were significantly different between
PC and NC2. However, the digestibility coefficients of these amino acids in $\mathrm{PC}$ and $\mathrm{NCl}$ were similar. Phytase was able to significantly increase the digestibility coefficient of threonine in diets supplemented with enzymes in contrast to NC1 $(p<0.05)$, while the enzyme combination (Phy + E) significantly improved the digestibility of methionine and threonine in the supplemented diet compared to the NC2 $\operatorname{diet}(p<0.05)$.

Overall, the enzyme combination (Phy $+E)$ increased the digestibility coefficients of amino acids by $2.62 \%$ (from $88.97 \%$ to 91.30\%) compared to the NC2 diet without supplementation, while the effect solely of phytase was $2.70 \%$ greater than that of the NC1 diet without this enzyme $(91.68 \%$ vs $89.27 \%)$.

The positive effects of phytase on protein use observed in this work are consistent with the findings of previous studies that reported improvements in the ileal digestibility of amino acids in broilers fed diets based on corn and soybean meal (Santos, Hruby, Pierson, Remus, \& Sakomura, 2008; Rutherfurd et al., 2012; Pieniazek et al., 2017). According to Rutherfurd et al. (2012), the negative effects of phytate on amino acid digestibility are due to the direct association between phytate phosphate groups and the basic amino acid side chains of dietary proteins, which reduces the solubility and digestibility of these nutrients, as well as to the inhibition of digestive enzymes, including pepsin and trypsin, by phytate. 
Table 6

Effect of supplementation with exogenous enzymes on the apparent ileal digestibility coefficient of amino acids in broilers

\begin{tabular}{|c|c|c|c|c|c|c|c|}
\hline \multirow{2}{*}{ Variable } & \multicolumn{5}{|c|}{ Treatment } & \multirow[b]{2}{*}{ SEM } & \multirow[b]{2}{*}{ P-value } \\
\hline & $\mathrm{PC}^{1}$ & $\mathrm{NC}^{2}{ }^{2}$ & $\mathrm{NC}^{3}$ & NC1 + Phy & $\begin{array}{c}\mathrm{NC} 2+ \\
\text { Phy + E }\end{array}$ & & \\
\hline \multicolumn{8}{|c|}{ Essential amino acids (\%) } \\
\hline Arginine & $91.92 \mathrm{abc}$ & $91.31 b c$ & $90.95 c$ & $93.22 a$ & $92.91 \mathrm{ab}$ & 0.0356822 & 0.001 \\
\hline Histidine & $90.65 a$ & $87.92 b$ & $88.13 b$ & $90.63 a$ & $90.62 a$ & 0.0479895 & 0.001 \\
\hline Isoleucine & $91.00 a b c$ & $89.44 b c$ & $89.06 c$ & $91.62 a$ & 91.19ab & 0.0432537 & 0.004 \\
\hline Leucine & $90.37 a b$ & 88.83b & $88.65 b$ & $91.22 a$ & $90.47 a b$ & 0.0431919 & 0.005 \\
\hline Lysine & $92.21 \mathrm{ab}$ & 91.59ab & $90.77 b$ & $93.01 a$ & $93.74 a$ & 0.0339794 & 0.003 \\
\hline Methionine & $99.55 a b$ & $99.06 b c$ & $98.47 c$ & $99.45 a b$ & $100.04 a$ & 0.0204844 & 0.001 \\
\hline Phenilalanine & $90.29 a b c$ & $89.37 b c$ & $89.19 c$ & $91.69 a$ & $91.50 a b$ & 0.0440278 & 0.003 \\
\hline Threonine & $89.20 a b$ & $86.91 b c$ & $85.88 \mathrm{c}$ & $90.49 a$ & $89.24 a b$ & 0.0680209 & 0.001 \\
\hline Valine & $90.25 a$ & $88.78 a$ & $88.41 a$ & $90.77 a$ & $90.74 a$ & 0.0484285 & 0.022 \\
\hline $\begin{array}{l}\text { Total essential amino } \\
\text { acids }\end{array}$ & $91.38 a b c$ & $90.07 \mathrm{bc}$ & 89.61c & $92.19 a$ & 91.78ab & 0.0417278 & 0.005 \\
\hline \multicolumn{8}{|c|}{ Non-essential amino acids (\%) } \\
\hline Alanine & $89.87 a$ & $87.32 b$ & $87.07 b$ & $90.13 a$ & $89.55 a b$ & 0.0533374 & 0.001 \\
\hline Aspartic acid & $89.26 a b$ & $87.64 b$ & $87.41 b$ & $90.95 a$ & $91.41 a$ & 0.0576453 & 0.001 \\
\hline Cysteine & $87.51 a$ & $85.42 a b$ & 83.60b & $87.40 a$ & $86.84 a b$ & 0.0708953 & 0.019 \\
\hline Glutamic acid & $91.63 a b c$ & $91.13 c$ & $91.29 b c$ & $93.24 a$ & 92.94ab & 0.0362221 & 0.002 \\
\hline Glycine & $87.79 a$ & $85.26 a$ & $85.32 a$ & $88.13 a$ & $87.43 a$ & 0.0584134 & 0.015 \\
\hline Proline & $90.22 a$ & 87.83ab & $86.99 b$ & $90.26 a$ & 88.85ab & 0.0528881 & 0.002 \\
\hline Serine & $89.21 a b$ & $86.84 b$ & $87.10 b$ & $90.89 a$ & $90.29 a$ & 0.0618352 & 0.001 \\
\hline Tyrosine & $91.05 a$ & 88.73ab & 87.78b & $90.70 a$ & $90.28 a b$ & 0.0528718 & 0.003 \\
\hline $\begin{array}{l}\text { Total non-essential } \\
\text { amino acids }\end{array}$ & $90.16 a b$ & 88.57b & $88.41 b$ & $91.23 a$ & $90.88 a$ & 0.0474608 & 0.002 \\
\hline Total amino acids (\%) & $90.73 a b c$ & $89.27 b c$ & $88.97 c$ & $91.68 a$ & $91.30 a b$ & 0.0447147 & 0.002 \\
\hline
\end{tabular}

a-cMeans in the same row with different letters differ significantly $(P<0.05)$ by Tukey's test.

Abbreviations: $\mathrm{E}$, enzymatic complex.

$1 \mathrm{PC}=$ positive control (diet meeting the nutritional requirements of broilers).

2NC1 = negative control 1 (PC minus $68 \mathrm{kcal} / \mathrm{kg} \mathrm{EM;} \mathrm{0,15 \%} \mathrm{AP} \mathrm{and} \mathrm{0,16 \%} \mathrm{Ca).}$

3NC2 = negative control 2 (PC minus $101 \mathrm{kcal} / \mathrm{kg} \mathrm{EM;} \mathrm{0,15 \%} \mathrm{AP} \mathrm{and} \mathrm{0,16 \%} \mathrm{Ca).}$

However, theadverseeffects of phytate on amino acid use are suggested to be largely associated with increased endogenous losses of amino acids in the intestine, rather than with a direct impact on protein retention in the diet
(Selle, Creswell, Cadagon, Partridge, \& Scott, 2006; Cowieson et al., 2017). Phytate may increase gastric secretions of pepsin and $\mathrm{HCl}$ due to the formation of binary protein-phytate complexes in the digestive tract of broilers 
(Selle, Cowieson, Cowieson, \& Ravindran, 2012). In addition, increased pepsin secretion can trigger higher outflow of protective mucus, resulting in increased mucin secretion in birds (Cowieson, Acamovic, \& Bedford, 2004). In this study, phytase supplementation reduced endogenous inputs for protein digestion, which resulted in an improvement in the CSID of the amino acids threonine, leucine, aspartic acid, glutamic acid, glycine, and serine that predominate in endogenous proteins (Truong, Bold, Liu, \& Selle, 2015; Siegert et al., 2019; Walk \& Poernama, 2018).

Thus, the digestibility of amino acids, such as threonine, serine, aspartic acid, glycine, and leucine, which is substantially improved by phytase, can contribute significantly to the benefit of reduced endogenous flow. However, the improvements in alanine and histidine digestibility, suggested by the data in this study, are not mediated by the reduction in the endogenous flow of amino acids, but must be due to one of the other mechanisms proposed by Rutherfurd et al. (2012).

In addition, some authors consider cysteine, which can be found in the secondary domain of mucin, to be the amino acid most responsive to phytase (Cowieson et al., 2017; Dersjant-Li \& Kwakernaak, 2019). However, this amino acid did not respond significantly in this study. The variation in the responses of amino acids may be due to several animal and dietary factors, such as the age of the bird and types of ingredient, level of dietary $\mathrm{Ca}$, source and concentration of phytase, and the presence of antinutritional factors in the diet (Selle \& Ravindran, 2007).

In this study, although the phytase, carbohydrase, and protease combination was added to diets with a higher reduction in amino acid specifications, the combined use of these enzymes maintained the standardized ileal digestibility of amino acids at a similar level to that of the phytase-only treatment and the standard diet. Likewise, previous studies have observed the improved "value" of amino acids due to phytase and enzyme complex combinations (Francesch \& Geraert, 2009; Gallardo et al., 2019). This improvement was associated with the total or partial breakdown of the cell wall matrix to release starch, fat, protein, minerals, and phytate, allowing access by endogenous enzymes and phytase of their substrates (Slominski, 2011; Karimi et al., 2013; Kiarie, Romero, \& Ravindran, 2014).

\section{Conclusion}

Supplementation with phytase preserves the performance of broilers fed diets deficient in $\mathrm{AP}, \mathrm{Ca}$, and $\mathrm{ME}$ and improves the digestibility of amino acids. The addition of phytase in combination with an enzyme complex can increase the growth of birds, although these effects are not always additive.

\section{Acknowledgments}

The authors thank Suntaq Enzymes for the financial support to carry out this work and Coordination for the Improvement of Higher Education Personnel (CAPES-Brazil) for granting scholarship to the first author.

\section{References}

Akter, M. M., Graham, H., \& lji, P. A. (2017). Influence of different levels of calcium, non-phytate phosphorus and phytase on 
apparent metabolizable energy, nutrient utilization, plasma mineral concentration and digestive enzyme activities of broiler chickens. Journal of Applied Animal Research, 46(1), 278-286. doi: 10. 1080/09712119.2017.1295972

Amerah, A. M. (2015). Interactions between wheat characteristics and feed enzyme supplementation in broiler diets. Animal Feed Science Technology, 199(1), 1-9. doi: 10.1016/j.anifeedsci.2014.09.012

Amerah, A. M., Plumstead, P. W., Barnard, L. P., \& Kumar, A. (2014). Effect of calcium level and phytase addition on ileal phytate degradation and amino acid digestibility of broilers fed corn-based diets. Poultry Science, 93(4), 906-915. doi: 10.3382/ps. 2013-03465

Amerah, A. M., Romero, L. F., Awati, A., \& Ravindran, V. (2016). Effect of exogenous xylanase, amylase, and protease as single or combined activities on nutrient digestibility and growth performance of broilers fed corn/soy diets. Poultry Science, 96(4), 807-816. doi: 10.3382/ps/ pew297

Bournazel, M., Lessire, M., Klein, S., Même, N., Peyronnent, C., Quinsac, A., Duclos, M. J. \& Narcy, A. (2018). Phytase supplementation in diets rich in fiber from rapeseed enhances phosphorus and calcium digestibility but not retention in broiler chickens. Poultry Science, 97(5), 1627-1640. doi: 10.3382/ps/pex446

Choct, M. (1997). Feed non-starch polysaccharides: chemical structures and nutritional significance. Feed Milling International, 191(1), 13-26. doi: 10.1071/ AN15276
Cowieson, A. J., Acamovic, T., \& Bedford, M. R., (2004). The effects of phytase and phytic acid on the loss of endogenous amino acids and minerals from broiler chickens. British Poultry Science, 45(1), 101-108. doi: 10.1080/00071660410001668923

Cowieson, A. J., Aureli, R., Guggenbuhl, P., \& Fru-Nji, F. (2015). Possible involvement of myo-inositol in the physiological response of broilers to high doses of microbial phytase. Animal Production Science, 55(6), 710-719. doi: 10.1071/AN14044

Cowieson, A. J., \& Bedford, M. R. (2009). The effect of phytase and carbohydrase on ileal amino acid digestibility in monogastric diets: complimentary mode of action?. World's Poultry Science Journal, 65(4), 609-624. doi: 10.1017/S00 43933909000427

Cowieson, A. J., \& Ravindran, V. (2007). Effect of phytic acid and microbial phytase on the flow and amino acid composition of endogenous protein at the terminal ileum of growing broiler chickens. British Journal of Nutrition, 98(4), 745-752. doi: 10.1017/S0007114507750894

Cowieson, A. J., \& Roos, F. F. (2016). Toward optimal value creation through the application of exogenous monocomponent protease in the diets of nonruminants. Animal Feed Science and Technology, 221(Part B), 331-340. doi: 10. 1016/j.anifeedsci.2016.04.015

Cowieson, A. J., Ruckebusch, J.-P., Sorbara, J. O. B., Wilson, J. W., Guggenbuhl, P., \& Roos, F. F. (2017). A systematic view on the effect of phytase on ileal amino aciddigestibility in broilers. Animal Feed Science and Technology, 225(2017), 182-194. doi: 10. 1016/j.anifeedsci.2017.01.008 
Dersjant-Li, Y., Awati, A., Schulze, H., \& Partridge, G. (2015). Phytase in non-ruminant animal nutrition: a critical review on phytase activities in the gastrointestinal tract and influencing factors. Journal of the Science of Food and Agriculture, 95(5), 878-896. doi: 10.1002/jsfa.6998

Dersjant-Li, Y., \& Kwakernaak, C. (2019). Comparative effects of two phytases versus increasing the inorganic phosphorus content of the diet, on nutrient and amino acid digestibility in boilers. Animal Feed Science and Technology, 253(2019), 166-180. doi: 10. 1016/j.anifeedsci.2019.05.018

Dessimoni, G. V., Sakomura, N. K., Donato, D. C. Z., Goldflus, F., Ferreira, N. T., \& Dalólio, F. S. (2019). Effect of supplementation with Escherichia coli phytase for broilers on performance, nutrient digestibility, minerals in the tibia and diet cost. Semina: Ciências Agrárias, 40(2), 767-780. doi: 10. 5433/1679-0359.2019v40n2p767

Detmann, E., Souza, M. A. de, Valadares, S. C., Fo., Queiroz, A. C., Berchielli, T. T., Saliba, E. O. S. Azevedo, J. A. G. (2012). Métodos para análise de alimentos. Visconde do Rio Branco, MG: INCT-CA.

Diana, T. F., Albino, L. F. T., Rostagno, H. S., Almeida, B. F., Xavier, M. L., Jr., Aleixo, P. E.,... Calderando, A. A. (2020). Xylanase and $\beta$-glucanase in maize- and soybean mealbased diets for broilers. Semina: Ciências Agrárias, 41(6), 3259-3274. doi: 10.5433/ 1679-0359.2020v41n6Supl2p3259

Francesch, M., \& Geraert, P. A. (2009). Enzyme complex containing carbohydrases and phytase improves growth performance and bone mineralization of broilers fed reduced nutrient corn-soybean-based diets. Poultry Science, 88(9), 1915-1924. doi: 10.3382/ps.2009-00073

Fru-Nji, F., Kluenter, A., Fischer, M., \& Pontoppidan, K. (2011). A feed serine protease improves broiler performance and increases protein and energy digestibility. Japan Poultry Science Association, 48(4), 239-246. doi: 10.2141/ jpsa.011035

Gallardo, C., Dadalt, J. C., Kiarie, E., \& Trindade, A. T., Neto. (2017). Effects of multi carbohydrase and phytase on standardized ileal digestibility of amino acids and apparent metabolizable energy in canola meal fed to broiler chicks. Poultry Science, 96(9), 3305-3313. doi: 10.3382/ps/pex141

Gallardo, C., Dadalt, J. C., \& Trindade, A. T., Neto. (2018). Nitrogen retention, energy, and amino acid digestibility of wheat bran, without or with multicarbohydrase and phytase supplementation, fed to broiler chickens. Journal of Animal Science, 96(6), 2371-2379. doi: 10.1093/jas/sky062

Gallardo, C., Dadalt, J. C., \& Trindade, A. T., Neto. (2019). Carbohydrases and phytase with rice bran, effects on amino acid digestibility and energy use in broiler chickens. Animal, 14(3), 482-490. doi: 10. 1017/S1751731119002131

Jamroz, D., Jakobsen, K., Knudsen, K. E. B., Wiliczkiewicz, A., \& Orda, J. (2002). Digestibility and energy value of nonstarch polysaccharides in young chickens, ducks and geese, fed diets containing high amounts of barley. Comparative Biochemistry and Physiology Part A: Molecular \& Integrative Physiology, 131(3), 657-668. doi: 10.1016/S1095-64 33(01)00517-7 
Jaworski, N. W., Lærke, H. N., Bach Knudsen, K. E., \& Stein, H. H. (2015). Carbohydrate composition and in vitro digestibility of dry matter and nonstarch polysaccharides in corn, sorghum, and wheat and coproducts from these grains. Journal of Animal Science, 93(3), 1103-1113. doi: 10.2527/ jas2014-8147

Karimi, A., Min, Y., Lu, C., Coto, C., Bedford, M. R., \& Waldroup, P. W. (2013). Assessment of potential enhancing effects of a carbohydrase mixture on phytase efficacy in male broiler chicks fed phosphorusdeficient diets from 1 to 18 days of age. Poultry Science, 92(1), 192-198. doi: 10. 3382/ps.2012-02558

Kiarie, E., Romero, L. F., \& Ravindran, V. (2014). Growth performance, nutrient utilization, and digesta characteristics in broiler chickens fed corn or wheat diets without or with supplemental xylanase. Poultry Science, 93(5), 1186-1196. doi: 10.3382/ ps.2013-03715

Lu, H., Adedokun, S. A., Preynat, A., LegrandDefretin, V., Geraert, P. A., Adeola, O., \& Ajuwpn, K. M. (2013). Impact of exogenous carbohydrases and phytase on growth performance and nutrient digestibility in broilers. Canadian Journal of Animal Science, 93(2), 243-249. doi: 10.4141/ cjas2012-138

Mahmood, T., Mirza, M. A., Nawaz, H., Shahid, M., Athar, M., \& Hussein, M. (2017). Effect of supplementing exogenous protease in low protein poultry by-product meal based diets on growth performance and nutrient digestibility in broilers. Animal Feed Science, 228(1), 23-31. doi: 10.1016/j. anifeedsci.2017.01.012

Malathi, V., \& Devegowda, G. (2001). In vitro evaluation of nonstarch polysaccharide digestibility of feed ingredients by enzymes. Poultry Science, 80(3), 302305. doi: $10.1093 / p s / 80.3 .302$

Meng, X., \& Slominski, B. A. (2005). Nutritive values of corn, soybean meal, canola meal and peas for broiler chickens as affected by a multicarbohydrase preparation of cell wall degrading enzymes. Poultry Science, 84(8), 1242-1251. doi: 10.1093/ ps/84.8.1242

Montanhini, R. Neto, Ceccantini, M. L., \& Fernandes, J. I. (2012). Productive performance, intestinal morphology and carcass yield of broilers fed conventional and alternative diets containing commercial enzymatic complex. Poultry Science, 11(8), 505-516. doi: 10.3923/ ijps.2012.505.516

Murugesan, G. R., Romero, L. F., \& Persla, M. E. (2014). Effects of protease, phytase and a Bacillus sp. direct-fed microbial on nutrient and energy digestibility, ileal brush border digestive enzyme activity and cecal short- chain fatty acid concentration in broiler chickens. Plos One, 9(7), e101888. doi: 10.13 71/journal.pone.0101888

Olukosi, O. A., \& Adeola, O. (2008). Whole body nutrient accretion, growth performance and total tract nutrient retention responses of broilers to supplementation of xylanase and phytase individually or in combination in wheat-soybean meal based diets. Journal of Poultry Science, 45(3), 192-198. doi: 10.21 41/jpsa.45.192

Olukosi, O. A., Cowieson, A. J., \& Adeola, O. (2007). Age-related influence of a cocktail of xylanase, amylase, and protease or phytase individually or in combination in broilers. Poultry Science, 86(1), 77-86. doi: 10.1093/ps/86.1.77 
Pieniazek, J., Smith, K. A., Williams, M. P., Manangi, M. K., Vazquez-Anon, M., Solbak, A., Miller, M., \& Lee, T. (2017). Evaluation of increasing levels of a microbial phytase in phosphorus deficiente broiler diets via live broiler performance, tibia bone ash, apparent metabolizable energy, and amino acid digestibility. Poultry Science, 96(2), 370-382. doi: 10.3382/ps/pew225

R Core Team (2019). R: A language and environment for statistical computing. Vienna, Austria: R Foundation for Statistical Computing. Retrieved from https://www.R-project.org/

Rahimi, Z. S., Modirsanei, M., \& Mansoori, B. (2020). The effect of enzymatic feed pretreatment on bioavailability of phytate phosphorous, performance, and bone indices of tibia in broilers. Journal of Applied of Poultry Research, 9(2), 372382. doi: 10.1016/j.japr.2019.12.008

Ribeiro, V., Jr., Salguero, S. C., Gomes, G., Barros, V. R. S. M., Silva, D. L., Barreto, S. L. T.,... Albino, L. F. T. (2016). Efficacy and phosphorus equivalency values of two bacterial phytases (Escherichia coli and Citrobacter braakii) allow the partial reduction of dicalcium phosphate added to the diets of broiler chickens from 1 to 21 days of age. Animal Feed Science and Technology, 221(Part A), 226-233. doi: 10. 1016/j.anifeedsci.2016.09.008

Romero, L. F., Parsons, C. M., Utterback, P. L., Plumstead, P. W., \& Ravindran, V. (2013). Comparative effects of dietary carbohydrases without or with protease on the ileal digestibility of energy and amino acids and AMEn in young broilers. Animal Feed Science Technology, 181(1-4), 3544. doi: 10.1016/j.anifeedsci.2013.02.001
Rostagno, H. S., Albino, L. F. T., Hannas, M. I., Donzele, J. L., Sakomura, N. K., Perazzo, F. G.,... Brito, C. O. (2017). Brazilian tables for poultry and swine: composition of feedstuffs and nutritional requirements (4nd ed.). Viçosa, MG: UF, Animal Science Department.

Rutherfurd, S. M., Chung, T. K., Thomas, D. V., Zou, M. L., \& Moughan, P. J. (2012). Effect of a novel phytase on growth performance, apparent metabolizable energy, and the availability of minerals and amino acids in a low-phosphorus corn-soybean meal diet for broilers. Poultry Science, 91(5), 1118-1127. doi: 10.3382/ps.2011-01702

Sakomura, N. K., \& Rostagno, H. S. (2016). Research methods in monogastric nutrition (2nd ed.). Jaboticabal, SP: FUNEP.

Santos, F. R., Hruby, M., Pierson, E. E. M., Remus, J. C., \& Sakomura, N. K. (2008). Effect of phytase supplementation in diets on nutrient digestibility and performance in broiler chicks. Journal of Applied Poultry Research, 17(2), 191-201. doi: 10.3382/ japr.2007-00028

Schramm, V. G., Durau, J. F., Barrilli, L. N. E., Sorbara, J. O. B., Cowieson, A. J., Felix, A. P., \& Maiorka, A. (2017). Interaction between xylanase and phytase on the digestibility of corn and a corn/soy diet for broiler chickens. Poultry Science, 96(5), 1204-1211. doi: 10.3382/ps/pew356

Siegert, W., Zuber, T., Sommerfeld, V., Krieg, J., Feuerstein, D., Kurrle, U., \& Rodehutscord, M. (2019). Prececal amino acid digestibility and phytate degradation in broiler chickens when using different oilseed meals, phytase and protease supplements in the feed. Poultry Science, 98(11), 5700-5713. doi: 10.3382/ps/pez355 
Selle, P. H., Creswell, D. C., Cadagon, D. J., Partridge, G. G., \& Scott, T. (2006). Phytase supplementation of wheat based broiler diets reduces dependence on meat and bone meal. Journal of Poultry Science, 43(4), 330-338. doi: 10.2141/jpsa.43.330

Selle, P. H., \& Ravindran, V. (2007). Microbial phytase in poultry nutrition. Animal feed Science and Technology, 135(1-2), 1-41. doi: 10.1016/j.anifeedsci.2006.06.010

Selle, P. H., Cowieson, A. J., Cowieson, N. P., \& Ravindran, V. (2012). Protein-phytate interactions in pig and poultry nutrition: a reappraisal. Nutrition Research Reviews, 25(1), 1-17. doi: 10.1017/s09544224110 00151

Slominski, B. A. (2011). Recent advances in research on enzymes for poultry diets. Poultry Science, 90(9), 2013-2023. doi: 10.3382/ps.2011-01372

Truong, H. H., Bold, R. M., Liu, S. Y., \& Selle, P. H. (2015). Standard phytase inclusion in maize-based broiler diets enhances digestibility coefficients of starch,amino acids and sodium in four small intestinal segments and digestive dynamics of starch and protein. Animal Feed Science Technology, 209(1), 240-248. doi: 10.10 16/j.anifeedsci.2015.08.012

Van Keulen, J., \& Young, B. A. (1977). Evaluation of Acid-Insoluble Ash as a Natural Marker in Ruminant Digestibility Studies. Journal of Animal Science, 44(2), 282-287. doi: 10.2527/jas1977.442282x

Walk, C. L., Santos, T. T., \& Bedford, M. R (2014). Influence of superdoses of a novel microbial phytase on growth performance, tibia ash, and gizzard phytate and inositol in young broilers. Poultry Science, 93(5), 1172-1177. doi: 10.3382/ps.2013-03571

Walk, C. L., Pirgozliev, V., Juntunen, K., Paloheimo, M., \& Ledoux, D. R. (2018). Evaluation of novel protease enzymes on growth performance and apparent ileal digestibility of amino acids in poultry: enzyme screening. Poultry Science, 97(6), 2123-2138. doi: 10.3382/ps/pey080

Walk, C. L., \& Poernama, F. (2018). Evaluation of phytase, xylanase, and protease in reduced nutrient diets fed to broilers. Journal Applied Poultry Research, 28(1), 85-93. doi: 10.3382/japr/pfy022

Walk, C. L. \& Rama Rao, S. V. (2020). Increasing dietary phytate has a significant antinutrient effect on apparent ileal amino acid digestibility and digestible amino acid intake requiring increasing doses of phytase as evidenced by prediction equations in broilers. Poultry Science, 99(1), 290-300. doi: 10.3382/ps/pez489

Yuan, L., Wang, M., Zhang, X., \& Wang, Z. (2017). Effects of protease and non-starch polysaccharide enzyme on performance, digestive function, activity and gene expression of endogenous enzyme of broilers. Plos One, 12(3), e0173941. doi: 10.1371/journal.pone.0173941

Ziarat, M. M., Kermanshahi, H., Mogaddam, H. N., \& Heravi, R. M. (2020). Performance of an Escherichia coli phytase expressed in Lactococcus lactis on nutriente retention, boné traits and intestinal morphology in broiler chickens. Journal of Animal Physiology and Animal Nutrition, 104(3), 1-9. doi: 10.1111/jpn.13332 